\title{
Water usage in the Gaza Strip: recommendations from a literature review and consultations with experts
}

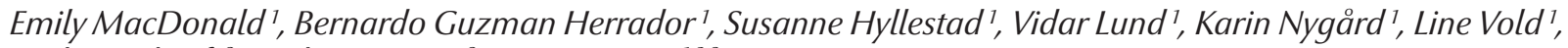
Mohamed Lafi ${ }^{3}$, Walaa Ammar ${ }^{3}$, Bjørn Iversen 1,2,3

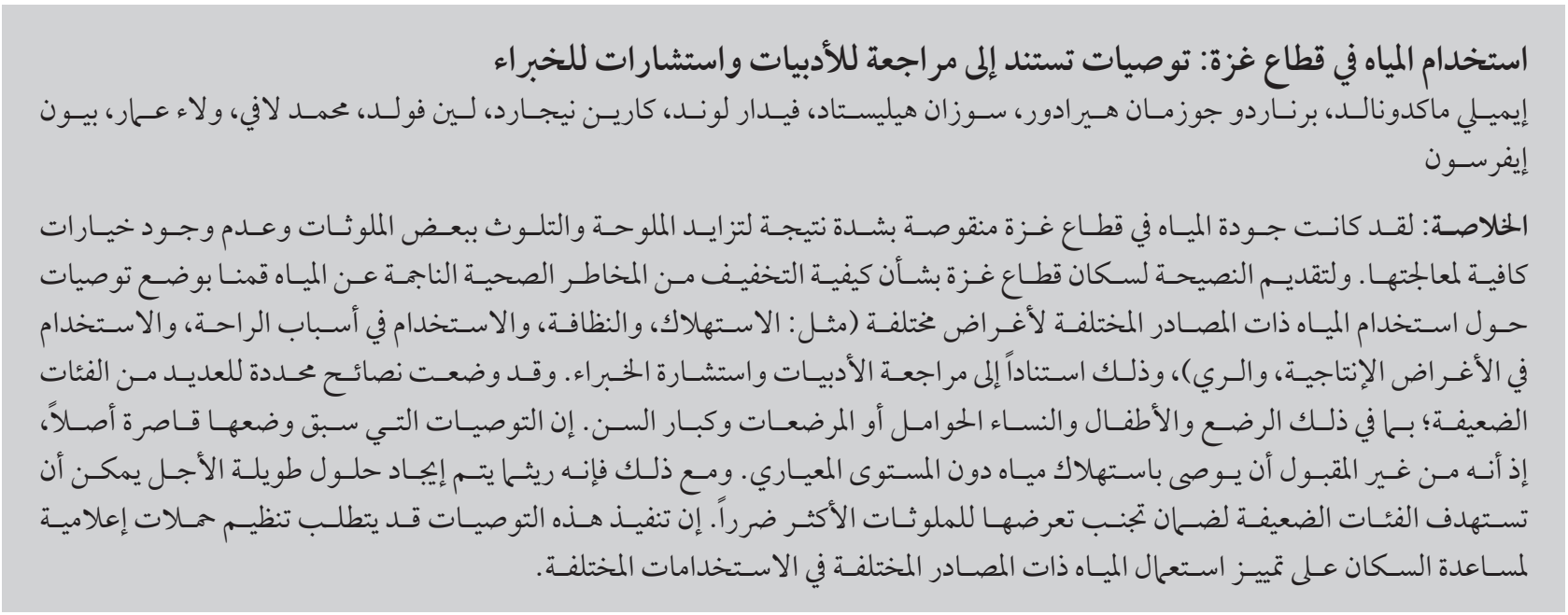

ABSTRACT Water quality in the Gaza Strip has been severely compromised due to increasing salinity, contamination with pollutants, and lack of adequate treatment options. To provide the population of the Gaza Strip with advice on how to mitigate health risks from water we developed recommendations on using water from different sources for different purposes (such as for consumption, hygiene, amenities, and irrigation) based on a literature review and consultation with experts. Specific advice was developed for several vulnerable groups, including infants, children, pregnant or lactating women, and elderly people. The recommendations are inherently limited, as it is unacceptable to recommend consuming water that is of substandard quality. However, pending long-term solutions, information can be targeted to vulnerable groups to ensure that exposure to the most harmful contaminants is avoided. The implementation of these recommendations may require information campaigns to assist the population in differentiating water from different sources for different uses.

\section{Utilisation de l'eau dans la Bande de Gaza : recommandations reposant sur une analyse documentaire et des consultations d'experts}

RÉSUMÉ La qualité de l'eau dans la Bande de Gaza a été grandement compromise du fait de l'augmentation de la salinité, de la contamination par les polluants, et du manque d'options de traitement appropriées. Afin de conseiller la population de la Bande de Gaza sur la façon de réduire les risques sanitaires liés à l'eau, nous avons mis au point des recommandations pour l'utilisation de l'eau provenant de différentes sources en vue d'usages variés (consommation; hygiène; utilisation des infrastructures y compris le lavage des voitures et l'arrosage de la pelouse, production et irrigation), sur la base d'une analyse documentaire et de consultations d'experts. Des conseils spécifiques ont été mis au point pour différents groupes vulnérables tels que les nourrissons, les enfants, les femmes enceintes ou allaitantes, et les personnes âgées. Les recommandations mises au point sont nécessairement limitées ; il est en effet inacceptable de recommander la consommation d'une eau ne répondant pas aux normes. Cependant, en attente de solutions sur le long terme, les groupes vulnérables peuvent être ciblés afin de garantir que l'exposition aux contaminants les plus dangereux soit évitée. La mise en place de ces recommandations pourrait nécessiter des campagnes d'information pour aider les populations à reconnaitre l'eau de différentes sources en vue d'usages variés.

${ }^{7}$ Norwegian Institute of Public Health, Oslo, Norway. (Correspondence to: Emily MacDonald: emily.macdonald@fhi.no)²Palestinian National Institute of Public Health. ${ }^{3}$ World Health Organization, Occupied Palestinian Territory.

Received: 10/06/16; accepted: 22/09/16 


\section{Introduction}

The Gaza Strip is approximately 365 $\mathrm{km}^{2}$ and home to more than 1.85 million people who live in 5 governorates (1). The population is projected to grow to 3.7 million inhabitants by 2035 (2). One of the main challenges facing the growing population is access to potable water. Water in the Gaza Strip is sourced primarily from the coastal aquifer, which has been infiltrated by the Mediterranean sea, leading to increased salinity in the groundwater. Extraction from the coastal aquifer in 2010 was estimated to be 170 million $\mathrm{m}^{3} /$ year, but the annual sustainable yield of the aquifer within the Gaza Strip is estimated to be 55 million $\mathrm{m}^{3} /$ year (3). Contamination of water resources with fertilizers, pesticides and solid waste, as well as a lack of adequate water and sewage treatment options, including desalination facilities, has further compromised the quality of the water $(4,5)$. It is estimated that the water extracted from the coastal aquifer will be unusable by as early as 2016, with the damage becoming irreversible by 2020 (6). In addition, damage to and destruction of the infrastructure due to the ongoing conflict with Israel and blockade of the Gaza Strip has gone unrepaired, which further complicates the situation (7).

It is essential that the public health and water authorities in the Gaza Strip pursue long-term solutions for the worsening water crisis. However, the population relies on the existing water resources, despite the insufficient quantity and questionable quality. Therefore, as part of an initiative to support the establishment of the Palestinian National Institute of Public Health (PNIPH), the Norwegian Institute of Public Health (NIPH) was commissioned by the World Health Organization (WHO) to collaborate with the PNIPH, WHO and the Palestinian Ministry of Health to provide the population in the Gaza Strip with clear advice on how to mitigate health risks from water.

\section{Water sources in the Gaza Strip}

Piped water in the Gaza Strip generally originates from the coastal aquifer, which extends from Haifa to the Sinai desert to Hebron Mountain. Water from the aquifer is drawn from deep wells and is used for domestic, agricultural and industrial purposes. However, the quality of the water sourced from the coastal aquifer has been severely compromised due to the infiltration of seawater and contamination from chemicals, such as pesticides and fertilizers $(8,9)$.

Desalination has been pursued as a means of increasing the amount of potable water in the Gaza Strip. Currently, there are 7 public desalination facilities run by the Coastal Municipalities Water Utility, at least 40 smallscale private desalination plants, and more than 20000 households using reverse osmosis units. Drinking water from desalination plants is sold from water tankers. As much as $83 \%$ of the population uses water from tankers as their primary source of household water (10). According to a water-quality monitoring campaign conducted in 2009, the water from desalination plants is of good microbiological and chemical quality (11). However, bacteriological contamination has been detected in samples taken from distribution points and in samples taken from household storage tanks, owing to contamination from non-hygienic handling and storage (12).

Bottled water in the Gaza Strip is both produced locally (using the aquifer as a source) and imported from Egypt, Israel, Jordan, Turkey and the West Bank. It has been estimated that $80 \%$ of the total amount of bottled water consumed in the Gaza Strip is imported, according to information provided by managers of large stores in Gaza ( $\mathrm{S}$. Lubbad, Public Health Laboratory, Palestinian Ministry of Health, personal communication, 2012). Due to a lack of systematic monitoring of the production and import of bottled water, there is limited information about the overall microbiological quality.

The harvesting of rainwater, commonly practiced in the West Bank (13), is not generally conducted by private households in the Gaza Strip. A 2008 study found that residents of the Gaza Strip would be willing to adopt on-site rooftop rainwater filtration systems in urban areas where land is available, but financial incentives from local authorities would be necessary to make this alternative more attractive (14). Given that the long-term annual average rainfall in Gaza is $327 \mathrm{~mm}$, with uneven geographical distribution and large fluctuations in quantity from year to year (9), and there is hardly any precipitation from May through September, the viability of rainwater collection as major source of water in the Gaza Strip is limited.

\section{Methods}

\section{Review of literature and water- quality guidelines}

To develop evidence-based recommendations for water use, a literature review was conducted to identify all studies related to water in the Gaza Strip. The search for peer-reviewed literature was conducted during July 2013 in the Ovid MEDLINE and Scopus databases, using general and specific terms related to "water" and "Gaza". Titles and abstracts were screened for relevance by two reviewers. Relevant articles were classified into thematic areas. Any recommendations proposed in the literature for addressing water quality in the Gaza Strip were extracted in order to potentially support the recommendations developed by the NIPH.

A total of 304 article titles were obtained using the search terms. Of these, 87 relevant original articles were 
identified and classified under 11 thematic areas. Only nine studies (15-23) examined the association between water quality and health effects (Table 1). In the literature describing contaminants in the water supply in the Gaza Strip, salt was the most notable cause of decreased water quality, followed by nitrates and infectious organisms. There is negligible information about the health effects of specific contaminants in the Gaza Strip, such as heavy metals and pesticides. The recommendations proposed in the literature predominantly emphasized the overall need to improve water resources. The full methods and results of the literature review and review of water guidelines are presented in a report by the NIPH and PNIPH (24).

A review of the Palestinian Water Authority's (PWA's) and international water-quality guidelines was conducted to propose practical recommendations based on the data about using the water available in the Gaza Strip and how the population could mitigate the health risks associated using it. For some parameters, the PWA's guidelines (11) are less restrictive than WHO's guidelines (25). Those PWA parameters that differ from WHO's guidelines are generally related to natural chemical constituents in the water. When compared with the results from regular testing for chemical contaminants in wells in the Gaza Strip from 2010 (169 wells), 2011 (173 wells) and 2012 (193 wells), levels for several parameters exceeded the limits recommended by $\mathrm{WHO}$ and the PWA (Palestinian Water Authority, personal communication, 2013). For example, from 2010 to 2012 the average chlorine levels observed in wells varied from 50 $\mathrm{mg} / \mathrm{L}$ to $11476 \mathrm{mg} / \mathrm{L}$, which exceeds the recommended maximum in both WHO's and and the PWA's guidelines (WHO's guidelines specify a maximum of $250 \mathrm{mg} / \mathrm{L}$ and the PWA specifies 600 $\mathrm{mg} / \mathrm{L}$ ). Nitrate levels up to $528 \mathrm{mg} / \mathrm{L}$ also exceeded the recommended limits in both guidelines (WHO's guidelines: maximum $50 \mathrm{mg} / \mathrm{L}$; PWA guidelines:
$70 \mathrm{mg} / \mathrm{L}$ ). Although the routine testing of wells does not include microbiological parameters, high levels of total and faecal coliform bacteria have also been found in water samples collected from groundwater wells, particularly those near wastewater treatment ponds, resulting from contamination with sewage $(10,26)$.

\section{Results}

\section{Development of recommendations for water usage}

The evidence collected through the literature review was presented to experts and key stakeholders in the Gaza Strip and Norway by the Palestinian Ministry of Health, the NIPH, the PWA, the Coastal Municipalities Water Utility and WHO. Through a consultative process, recommendations were developed about using water from different sources for different purposes (consumption; hygiene; amenities, such as car washing or lawn watering; production; and irrigation) (Table 2). Water used for consumption and hygiene has direct consequences for human health, both in relation to physiological needs and for controlling diverse infectious and noninfectious waterborne diseases. Water used for amenities (such as for watering lawns) may not directly affect human health, but water used for production (such as for raising animals, or for smallscale horticulture or construction) may be critical to sustaining livelihoods and, therefore, may have considerable indirect influence on human health. Water used for irrigation, such as for growing vegetables, demands significant amounts of water and was considered to be a separate category. In addition, the following vulnerable groups were defined

- Infants up to 6 months of age were considered to be at risk for methaemoglobinemia (or "blue baby syndrome"), for which the most common environmental cause is high levels of nitrates in drinking water. Other groups potentially susceptible to this condition include pregnant women and people deficient in glucose-6-phosphate dehydrogenase or methaemoglobin reductase (27).

- Children between 6 months and 5 years of age have an increased risk of morbidity and mortality from diarrhoeal diseases, generally resulting from the consumption of contaminated food and water.

- Pregnant women or lactating women may have an increased risk of, and severity of, illnesses, such as hepatitis E, from specific waterborne pathogens due to immune alterations that occur with advancing pregnancy $(28,29)$. In addition, contaminants such as pesticides can cross the placenta from the mother to the fetus, harming fetal development.

- Elderly people are predisposed to a greater frequency and severity of infections than the general population due to factors such as the presence of multiple underlying medical conditions, a weakened immune system, malnutrition, age-related changes in the gastrointestinal tract, the concurrent use of different medicines, delays in diagnosis, or a delayed or diminished response to therapy, or some combination of these (30).

Specific advice was developed for vulnerable groups, including not to drink piped water even after boiling (Table 3). We also recommended that infants should be exclusively breastfed. If infants are fed formula, bottled water may be used for the formula. However, due to a lack of evidence that bottled water is microbiologically safe, the water needs to be boiled before use.

\section{Discussion}

The water-use recommendations that we developed are inherently limited, as 


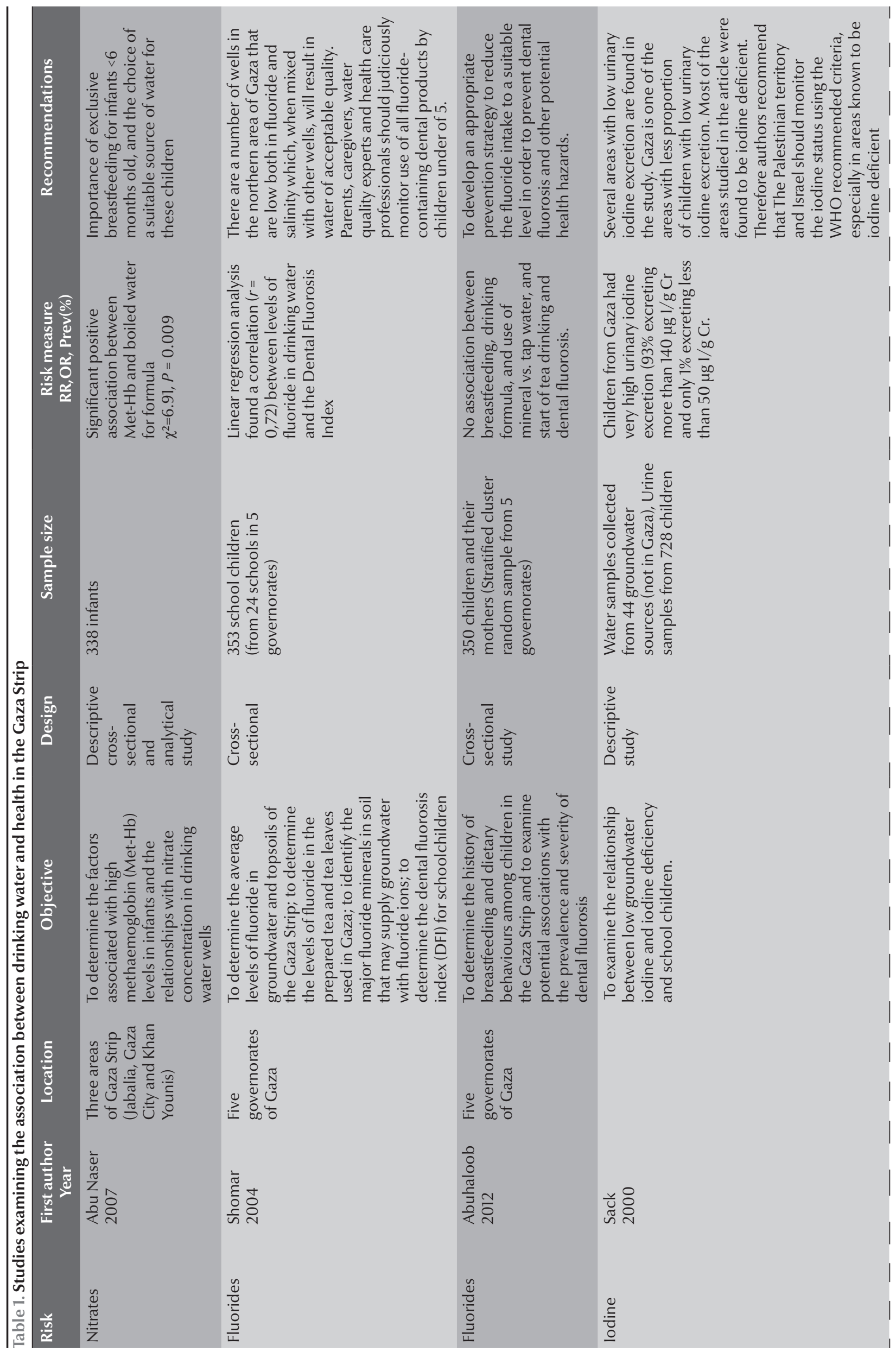




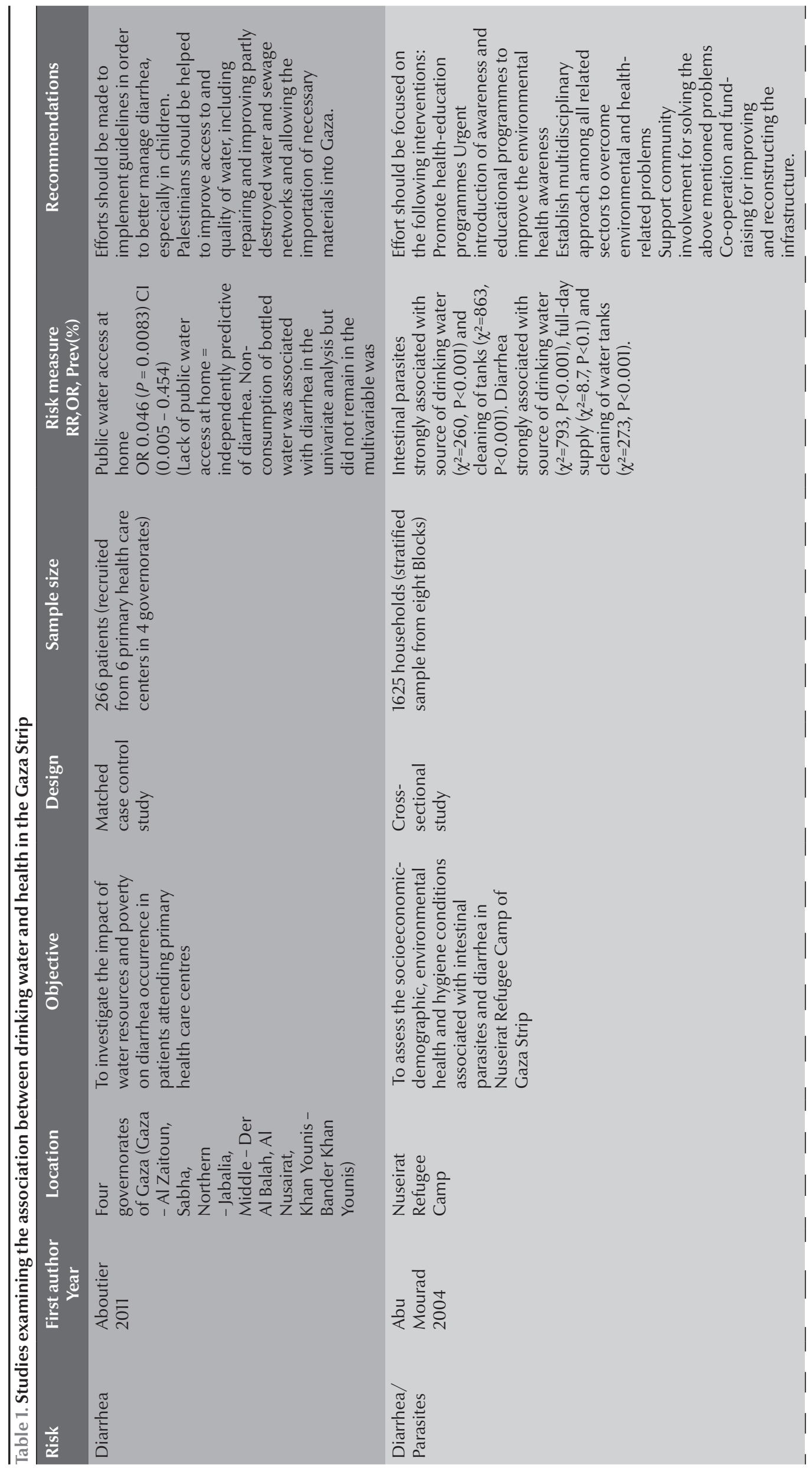




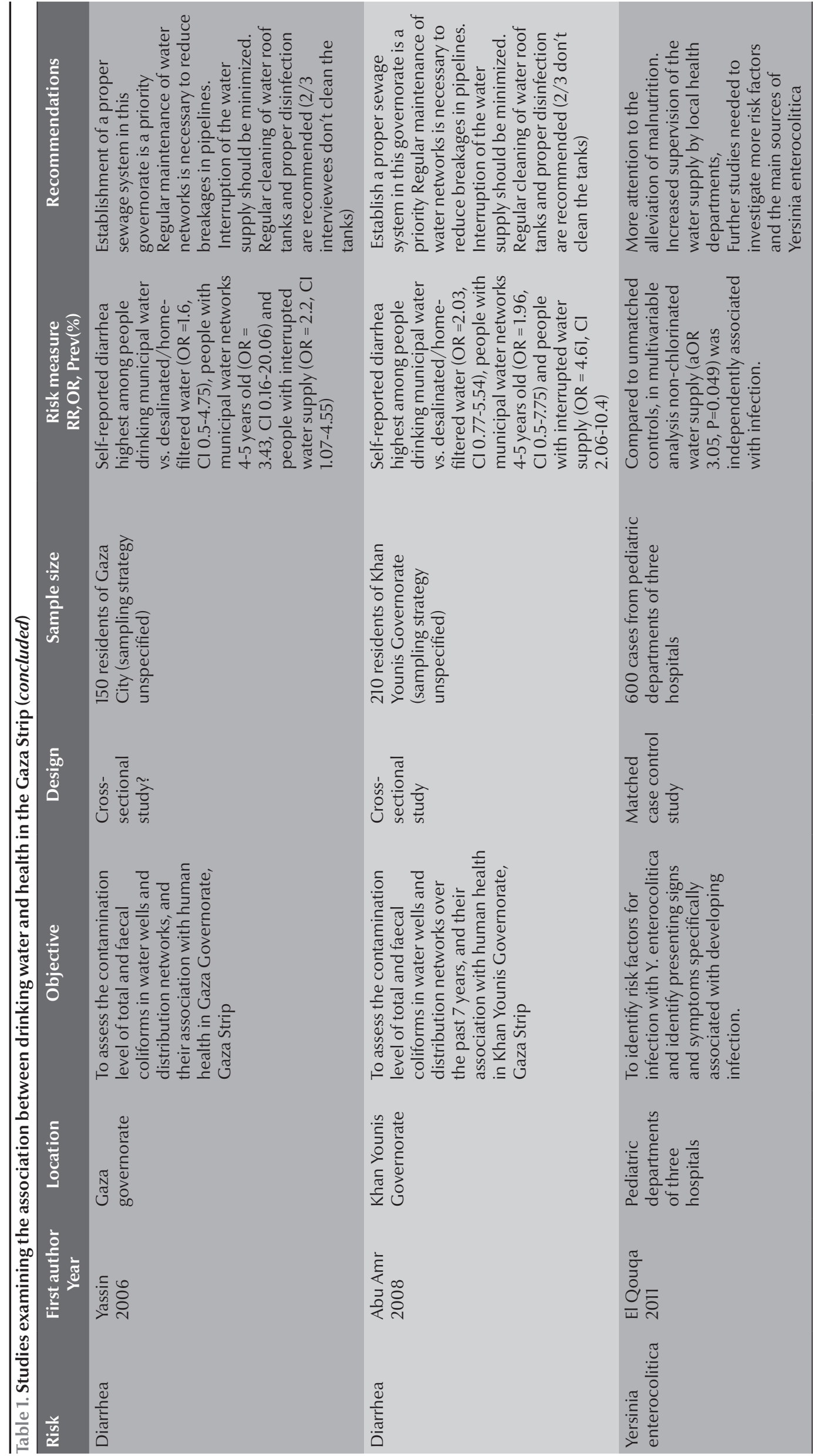




\begin{tabular}{|c|c|c|c|c|c|}
\hline Water use & $\begin{array}{l}\text { Water source } \\
\text { Piped water } \\
\text { (not } \\
\text { desalinated) }\end{array}$ & $\begin{array}{l}\text { Water delivered by } \\
\text { tankers (desalinated water } \\
\text { from treatment plants) }\end{array}$ & $\begin{array}{l}\text { Piped water } \\
\text { desalinated at home }\end{array}$ & Bottled water & $\begin{array}{l}\text { Rooftop-harvested } \\
\text { rainwater }^{\text {b }}\end{array}$ \\
\hline $\begin{array}{l}\text { Main } \\
\text { problems }\end{array}$ & $\begin{array}{l}\text { High in salt, } \\
\text { nitrates and } \\
\text { TDS; unknown } \\
\text { levels of } \\
\text { pesticides } \\
\text { and radiation; } \\
\text { limited data } \\
\text { about heavy } \\
\text { metals }\end{array}$ & $\begin{array}{l}\text { Microbial contamination } \\
\text { occurs due to non- } \\
\text { hygienic handling } \\
\text { of the water during } \\
\text { distribution; water is low } \\
\text { in minerals }\end{array}$ & $\begin{array}{l}\text { Quality varies } \\
\text { as domestic } \\
\text { desalination units } \\
\text { are often not } \\
\text { regulated }\end{array}$ & $\begin{array}{l}\text { Uncertainty } \\
\text { about } \\
\text { microbiological } \\
\text { contaminationc }\end{array}$ & $\begin{array}{l}\text { Not commonly } \\
\text { used at the } \\
\text { household level; } \\
\text { risk of microbial } \\
\text { contamination }\end{array}$ \\
\hline Consumption & $\begin{array}{l}\text { Should not be } \\
\text { consumed }\end{array}$ & $\begin{array}{l}\text { Should be consumed } \\
\text { only if water safety can be } \\
\text { ensured by disinfecting } \\
\text { and storing safely }\end{array}$ & $\begin{array}{l}\text { Should be } \\
\text { consumed only if } \\
\text { water safety can } \\
\text { be ensured by } \\
\text { disinfecting and } \\
\text { storing safely }\end{array}$ & $\begin{array}{l}\text { Can be } \\
\text { consumed but } \\
\text { must be properly } \\
\text { disinfected due } \\
\text { to the risk of } \\
\text { microbiological } \\
\text { contamination }^{c * *}\end{array}$ & $\begin{array}{l}\text { Currently not used } \\
\text { for consumption, } \\
\text { but may be } \\
\text { considered for } \\
\text { consumption } \\
\text { if treated } \\
\text { appropriately } \\
\text { (with filtration plus } \\
\text { disinfection) and } \\
\text { stored safely }\end{array}$ \\
\hline Hygiene & $\begin{array}{l}\text { Can be used } \\
\text { for hygiene } \\
\text { needs, but use } \\
\text { will probably } \\
\text { be limited in } \\
\text { areas where } \\
\text { the water is too } \\
\text { salty }\end{array}$ & $\begin{array}{l}\text { Can be used for hygiene } \\
\text { needs but with awareness } \\
\text { that water coming } \\
\text { from this source might } \\
\text { contain microbiological } \\
\text { contaminants }\end{array}$ & $\begin{array}{l}\text { Can be used for } \\
\text { hygiene needs but } \\
\text { with awareness } \\
\text { that water coming } \\
\text { from this source } \\
\text { might contain } \\
\text { microbiological } \\
\text { contaminants }\end{array}$ & $\begin{array}{l}\text { Can be used for } \\
\text { hygiene needs } \\
\text { but is likely to be } \\
\text { unaffordable for } \\
\text { these uses }\end{array}$ & $\begin{array}{l}\text { Currently not } \\
\text { used for hygiene } \\
\text { needs, but may } \\
\text { be considered } \\
\text { for hygiene } \\
\text { needs if treated } \\
\text { appropriately } \\
\text { (with filtration plus } \\
\text { disinfection) and } \\
\text { stored safely }\end{array}$ \\
\hline Amenities & $\begin{array}{l}\text { Can be } \\
\text { used for this } \\
\text { category }\end{array}$ & $\begin{array}{l}\text { Can be used for this } \\
\text { category }\end{array}$ & $\begin{array}{l}\text { Can be used for this } \\
\text { category }\end{array}$ & Not applicable & $\begin{array}{l}\text { Currently not used } \\
\text { for amenities, } \\
\text { but should not } \\
\text { be a problem for } \\
\text { this category, if } \\
\text { possible turbidity } \\
\text { is acceptable to } \\
\text { the consumer }\end{array}$ \\
\hline Production & $\begin{array}{l}\text { Can be used } \\
\text { for production, } \\
\text { but use as } \\
\text { drinking water } \\
\text { for animals will } \\
\text { be limited if it } \\
\text { is too salty }\end{array}$ & $\begin{array}{l}\text { Can be used for } \\
\text { production }\end{array}$ & $\begin{array}{l}\text { Can be used for } \\
\text { production }\end{array}$ & Not applicable & $\begin{array}{l}\text { Can be used for } \\
\text { production }\end{array}$ \\
\hline Irrigation & $\begin{array}{l}\text { Can be used } \\
\text { depending } \\
\text { on the plants/ } \\
\text { vegetables, } \\
\text { but in general } \\
\text { will be too salty }\end{array}$ & Not applicable & Not applicable & Not applicable & $\begin{array}{l}\text { Not applicable } \\
\text { (it is assumed } \\
\text { that this category } \\
\text { produces only a } \\
\text { small amount of } \\
\text { water) }\end{array}$ \\
\hline
\end{tabular}

${ }^{a}$ Water use has been categorized into five types: consumption (drinking and cooking), hygiene (including basic needs for personal and domestic cleanliness), amenities (such as car washing, lawn watering), production (such as, for raising animals or small-scale horticulture, or for construction ); irrigation (agriculture that needs water). ${ }^{b}$ Rainwater is not a significant source of domestic water but could be considered as a potential alternative source.

' There are uncertainties regarding the quality of bottled water. There is not enough evidence to document the quality of bottled water currently distributed and consumed in the Gaza Strip.

it is unacceptable to recommend that people consume water that is of substandard quality according to WHO's guidelines on drinking water (25). It is essential that long-term solutions are identified to ease the worsening water crisis. However, in the interim, groups at high risk from drinking contaminated water can be targeted to ensure that their exposure to the most harmful contaminants is avoided. The implementation of these recommendations may require 


\begin{tabular}{|c|c|c|c|c|c|}
\hline \multirow{2}{*}{$\begin{array}{l}\text { Vulnerable } \\
\text { group }\end{array}$} & \multicolumn{5}{|c|}{ Water source for consumption } \\
\hline & $\begin{array}{l}\text { Piped water } \\
\text { (not } \\
\text { desalinated) }\end{array}$ & $\begin{array}{l}\text { Water delivered by } \\
\text { tankers } \\
\text { (desalinated water from } \\
\text { treatment plants) }\end{array}$ & $\begin{array}{l}\text { Piped water } \\
\text { desalinated at } \\
\text { home }\end{array}$ & Bottled water & $\begin{array}{l}\text { Rooftop-harvested } \\
\text { rainwater }^{b}\end{array}$ \\
\hline $\begin{array}{l}\text { Infants } f \\
\leq 6 \text { months of } \\
\text { age }\end{array}$ & $\begin{array}{l}\text { Should } \\
\text { not be } \\
\text { consumed, } \\
\text { even if } \\
\text { boiled }\end{array}$ & $\begin{array}{l}\text { Can be consumed only } \\
\text { if water safety is ensured } \\
\text { by disinfecting it (for } \\
\text { example, by boiling) } \\
\text { and storing it safely }\end{array}$ & $\begin{array}{l}\text { Should not be } \\
\text { consumed, } \\
\text { even if boiled }\end{array}$ & $\begin{array}{l}\text { Can be consumed } \\
\text { but must } \\
\text { be properly } \\
\text { disinfected due } \\
\text { to the risk of } \\
\text { microbiological } \\
\text { contaminationc }\end{array}$ & $\begin{array}{l}\text { Currently not used for } \\
\text { consumption, but may } \\
\text { be considered if treated } \\
\text { appropriately (with } \\
\text { filtration plus disinfection) } \\
\text { and stored safely }\end{array}$ \\
\hline $\begin{array}{l}\text { Children aged } \\
6 \text { months to } 5 \\
\text { years }\end{array}$ & $\begin{array}{l}\text { Should } \\
\text { not be } \\
\text { consumed, } \\
\text { even if } \\
\text { boiled }\end{array}$ & $\begin{array}{l}\text { Should be consumed } \\
\text { only if water safety } \\
\text { can be ensured by } \\
\text { disinfecting it (for } \\
\text { example, by boiling) } \\
\text { and storing it safely }\end{array}$ & $\begin{array}{l}\text { Can be } \\
\text { consumed } \\
\text { after being } \\
\text { boiled if safety } \\
\text { is ensured by } \\
\text { disinfecting and } \\
\text { storing safely }\end{array}$ & $\begin{array}{l}\text { Can be consumed } \\
\text { but must } \\
\text { be properly } \\
\text { disinfected due } \\
\text { to the risk of } \\
\text { microbiological } \\
\text { contamination)c }\end{array}$ & $\begin{array}{l}\text { Currently not used for } \\
\text { consumption, but may } \\
\text { be considered if treated } \\
\text { appropriately (with } \\
\text { filtration plus disinfection) } \\
\text { and stored safely }\end{array}$ \\
\hline $\begin{array}{l}\text { Pregnant } \\
\text { and lactating } \\
\text { women }\end{array}$ & $\begin{array}{l}\text { Should } \\
\text { not be } \\
\text { consumed, } \\
\text { even if } \\
\text { boiled }\end{array}$ & $\begin{array}{l}\text { Should be consumed } \\
\text { only if water safety can } \\
\text { be ensured disinfecting } \\
\text { it (for example, by } \\
\text { boiling) and by storing } \\
\text { safely }\end{array}$ & $\begin{array}{l}\text { Should not be } \\
\text { used, even if } \\
\text { boiled }\end{array}$ & $\begin{array}{l}\text { Can be consumed } \\
\text { but must } \\
\text { be properly } \\
\text { disinfected due } \\
\text { to the risk of } \\
\text { microbiological } \\
\text { contamination)c }\end{array}$ & $\begin{array}{l}\text { Currently not used for } \\
\text { consumption, but may } \\
\text { be considered if treated } \\
\text { appropriately (with } \\
\text { filtration plus disinfection) } \\
\text { and stored safely }\end{array}$ \\
\hline Elderly people & $\begin{array}{l}\text { Should } \\
\text { not be } \\
\text { consumed, } \\
\text { even if } \\
\text { boiled }\end{array}$ & $\begin{array}{l}\text { Should be consumed } \\
\text { only if water safety } \\
\text { can be ensured by } \\
\text { disinfecting it (for } \\
\text { example, by boiling)y } \\
\text { and storing safely }\end{array}$ & $\begin{array}{l}\text { Can be } \\
\text { consumed } \\
\text { after being } \\
\text { boiled if safety } \\
\text { is ensured by } \\
\text { disinfecting and } \\
\text { storing safely }\end{array}$ & $\begin{array}{l}\text { Can be consumed } \\
\text { but must } \\
\text { be properly } \\
\text { disinfected due } \\
\text { to the risk of } \\
\text { microbiological } \\
\text { contamination)c }^{c}\end{array}$ & $\begin{array}{l}\text { Currently not used for } \\
\text { consumption, but may } \\
\text { be considered if treated } \\
\text { appropriately (with } \\
\text { filtration plus disinfection) } \\
\text { and stored safely }\end{array}$ \\
\hline
\end{tabular}

a It was assumed that water distributed by tankers is desalinated seawater, which suggests that nitrate levels would not be problematic.

${ }^{b}$ Rainwater is not a significant source of domestic water but could be considered as a potential alternative source.

${ }^{c}$ There are uncertainties regarding the quality of bottled water. There is not enough evidence to document the quality of bottled water currently distributed and consumed in the Gaza Strip.

information campaigns that assist the population in differentiating water from different sources for different uses.

Several measures can be implemented to improve water quality in the short term. Currently, chlorine is not added during transport to the desalinated water distributed by water tankers, so its use should be encouraged to ensure that safe water is delivered to customers. If desalinated water cannot be treated and safely stored, it should be boiled before consumption. Making improvements to water-quality monitoring in the Gaza Strip is also encouraged, including screening for heavy metals, radioactivity and pesticides every 5 years; screening for chemical parameters 4 times each year; and screening for microbial parameters every month. Targeted studies are needed to investigate the burden of disease associated with water consumed from different sources and districts in the Gaza Strip, including estimating the long-term effects of consuming substandard water.

\section{Acknowledgments}

The authors thank the Palestinian Ministry of Health, the Palestinian Water Authority, and the Coastal Municipalities Water Utility for their contributions.

Funding: This work was supported by project funding from the Norwegian Ministry of Foreign. Affairs, Norway.

Competing interests: None declared.

\section{References}

1. The Palestinians at the end of 2015. In: Palestinian Central Bureau of Statistics [website]. Ramallah: Palestinian Central Bureau of Statistics; 2015. (http://www.pcbs.gov.ps/site/512/ default.aspx?tablD=512\&lang=en\&ltemID=1566\&mid=3171\&w version=Staging, accessed 5 May 2016)
2. Coastal Municipalities Water Utility. Water status in the Gaza Strip and future plans. South Remal: Coastal Municipalities Water Utility; 2010 (http://commerce.iugaza.edu.ps/Portals/20/Users/016/16/16/WATERS 1.PDF, accessed 5 May 2016). 
3. Palestinian Water Authority. The Gaza Emergency Technical Assistance Programme (GETAP) on water supply to the Gaza Strip. Component 1 - the Comparative Study of Options for an additional supply of water for the Gaza Strip (CSO-G): the updated final report. Ramalla: Palestinian Water Authority; 2011 (https://www.humanitarianresponse.info/system/files/ documents/files/PWA\%20-\%20CSO-G\%20updated\%20Final. pdf, accessed 24 April 2016).

4. Protecting children from unsafe water in Gaza: strategy, action plan and project resources. Occupied Palestinian Territory: UNICEF; 2011 (http://www.unicef.org/oPt/FINAL_Summary_Protecting_Children_from_unsafe_Water_in_ Gaza_4_March_2011.pdf, accessed 24 April 2016).

5. World Bank. Assessment of restrictions on Palestinian water sector development. Washington, DC: World Bank; 2009 (Report No. 47657-GZ; http://documents.worldbank.org/ curated/en/775491468139782240/pdf/476570SR0P11511nsR eport18Apr2009111.pdf, accessed 5 May 2016).

6. United Nations Environment Programme. Environmental assessment of the Gaza strip following the escalation of hostilities in December 2008 - January 2009. Nairobi, Kenya: United Nations Environment Programme; 2009(http://www.unep. org/PDF/dmb/UNEP_Gaza_EA.pdf, accessed 24 April 2016).

7. United Nations Country Team. Gaza in 2020: a liveable place? . Jerusalem: Office of the United Nations Special Coordinator for the Middle East Peace Process; 2012 (http://www.unrwa. org/userfiles/file/publications/gaza/Gaza\%20in\%202020. pdf, accessed 16 May 2016).

8. Weinthal E, Vengosh A, Marei A, Kloppmann W. The water crisis in the Gaza Strip: prospects for resolution. Ground Water 2005;43(5):653-60. doi:10.1111/j.1745-6584.2005.00064.x.

9. <unknown $>9$. Palestinian Water Authority. Status report of water resources in the occupied state of Palestine - 2012. Palestinian Water Authority: West Bank and Gaza Strip; 2013 (http:// www.pwa.ps/userfiles/file/\%D8\%AA\%D9\%82\%D8\%A7\%D8 \%B1\%D9\%8A\%D8\%B1/\%D8\%AA\%D8\%B5\%D9\%86\%D9\%8A \%D9\%81\%201/WR\%20STATUS\%20Report-final\%20draft\%20 2014-04-01.pdf, accessed 5 May 2016).</unknown>

10. Palestinian Hydrology Group, UNICEF. Water, sanitation and hygiene: household survey, Gaza. West Bank and Gaza Strip: Palestinian Hydrology Group, UNICEF; 2010 (http://www. unicef.org/oPt/FINAL_WASH_REPORT.pdf, accessed 24 April 2016).

11. Gruppo di Volontariato Civilie, Palestinian Hydrology Group. Water quality monitoring campaigns: middle area of the Gaza Strip. West Bank and Gaza Strip: Gruppo di Volontariato Civilie, Palestinian Hydrology Group; 2009 (http://www. alazhar.edu.ps/arabic/Ewi/Researches/GazaPaper-new/ GVC_PHG\%20report.pdf, accessed 16 May 2016).

12. Aish AM. Drinking water quality assessment of the Middle Governorate in the Gaza Strip, Palestine. Water Resour Ind 2013;4:13-30. doi:10.1016/j.wri.2013.09.004.

13. Daoud AK, Swaileh KM, Hussein RM, Matani M. Quality assessment of roof-harvested rainwater in the West Bank, Palestinian Authority. J Water Health. 2011;9(3):525-33.

14. Nassar AHS. Socioeconomic aspects of rooftop rainwater harvesting in the Gaza Strip. Int J Emerg Technol Adv Eng. 2013;3(10):316-24 (http://www.ijetae.com/files/Volume3Issue10/IJETAE_1013_52.pdf, accessed 16 May 2016).

15. Abu Naser AA, Ghbn N, Khoudary R. Relation of nitrate contamination of groundwater with methaemoglobin level among infants in Gaza. East Mediterr Health J. 2007;13(5):994-1004.

16. Shomar B, Müller G, Yahya A, Askar S, Sansur R. Fluorides in groundwater, soil and infused black tea and the occurrence of dental fluorosis among school children of the Gaza Strip. J Water Health. 2004;2(1):23-35.

17. Abuhaloob L, Abed Y. Dietary behaviours and dental fluorosis among Gaza Strip children. East Mediterr Health J. 2013;19(7):657-63.

18. Sack J, Kaiserman I, Tulchinsky T, Harel G, Gutekunst R. Geographic variation in groundwater iodine and iodine deficiency in Israel, The West Bank and Gaza. J Pediatr Endocrinol Metab. 2000;13(2):185-90.

19. Abouteir A, El Yaagoubi F, Bioh-Johnsona I, Kamel A, Godard N, Cormerais $\mathrm{L}$, et al. Water access and attendance for diarrhea in primary health care centers, Gaza strip. Trans R Soc Trop Med Hyg. 2011;105(10):555-60. doi:10.1016/j.trstmh.2011.07.002.

20. Abu Mourad TA. Palestinian refugee conditions associated with intestinal parasites and diarrhoea: Nuseirat refugee camp as a case study. Public Health. 2004;118(2):131-42. doi:10.1016/j.puhe.2003.09.002.

21. Abu Amr SS, Yassin MM. Microbial contamination of the drinking water distribution system and its impact on human health in Khan Yunis Governorate, Gaza Strip: seven years of monitoring (2000-2006). Public Health. 2008;122(11):1275-83. doi:10.1016/j.puhe.2008.02.009.

22. Yassin MM, Amr SS, Al-Najar HM. Assessment of microbiological water quality and its relation to human health in Gaza Governorate, Gaza Strip. Public Health. 2006;120(12):1177-87. http://dx.doi.org/10.1016/j.puhe.2006.07.026.

23. El Qouqa IA, El Jarou MA, Samaha AS, Al Afifi AS, AI Jarousha AM. Yersinia enterocolitica infection among children aged less than 12 years: a case-control study. Int J Infect Dis. 2011;15(1):e48-53. doi:10.1016/j.ijid.2010.09.010.

24. Norwegian Institute of Public Health, Palestinian National Institute of Public Health. A systematic literature review and recommendations on water usage in the Gaza Strip. Oslo: Norwegian Institute of Public Health, Palestinian National Institute of Public Health; 2014 (https://www.humanitarianresponse.info/system/files/documents/files/PNIPH\%20-\%20 WHO\%20-\%20Gaza\%20water\%20report\%20final\%20210914. pdf, accessed 16 May 2016).

25. World Health Organization. Guidelines for drinkingwater quality, fourth edition. Geneva: World Health Organization; 2011 (http://apps.who.int/iris/bitstre am/10665/44584/1/9789241548151_eng.pdf, accessed 16 May 2016).

26. Melad KA. Evaluation of groundwater pollution with wastewater microorganisms in Gaza Strip, Palestine [thesis]. Cairo: Ain Shams University; 2002.

27. World Health Organization. Nitrate and nitrite in drinkingwater: background document for development of WHO Guidelines for drinking-water quality. Geneva: World Health Organization; 2011 (WHO/SDE/WSH/07.01/16/Rev/1; http:// www.who.int/water_sanitation_health/dwq/chemicals/nitratenitrite2ndadd.pdf, accessed 24 April 2016).

28. Hepatitis E: fact sheet. In: World Health Organization Media Centre [website]. Geneva: World Health Organization; 2015 (http://www.who.int/mediacentre/factsheets/fs280/en/, accessed 16 May 2016).

29. Sappenfield E, Jamieson DJ, Kourtis AP. Pregnancy and susceptibility to infectious diseases. Infect Dis Obstet Gynecol. 2013; 2013:752852. doi:10.1155/2013/752852.

30. Smith JL. Foodborne illness in the elderly. J Food Prot. 1998;61(9):1229-39. 